\title{
Wettability between Fe-Al alloy and sintered MgO
}

\author{
Ping SHEN, Lifeng ZHANG, Hao ZHOU, Ying REN, Yi WANG \\ School of Metallurgical and Ecological Engineering \\ University of Science and Technology Beijing \\ Beijing 100083, China \\ Corresponding author: Ying Ren, E-mail: renyingfour@163.com
}

\begin{abstract}
In the current study, the wettability between $\mathrm{Fe}-\mathrm{Al}$ alloy and sintered $\mathrm{MgO}$ substrate was investigated. The stable contact angle between the sintered $\mathrm{MgO}$ substrate and the liquid iron was approximately $134^{\circ}$ at $1550{ }^{\circ} \mathrm{C}$, hardly influenced by $\mathrm{Al}$ concentrations of $18 \mathrm{ppm}$ and $370 \mathrm{ppm}$ in the liquid iron. By changing hydrogen partial pressure from 0 vol\% to $1 \mathrm{vol} \%$, the oxygen partial pressure decreased. Meanwhile, the contact angle between the $\mathrm{MgO}$ substrate and the liquid iron with $370 \mathrm{ppm} \mathrm{Al}$ increased with the decrease of oxygen partial pressure. The oxygen partial pressure and contact angle were scarcely affected by increasing hydrogen partial pressure from 1 vol\% to 5 vol\%. In all cases with $370 \mathrm{ppm} \mathrm{Al}$ in the liquid iron, oxide layers were detected on the surface of iron samples. The oxidation of iron could be effectively prevented by increasing the hydrogen partial pressure. The $\mathrm{MgO}$ substrate was reduced to $\mathrm{Mg}$ vapor in the reducing atmosphere at a high temperature. Then the $\mathrm{Mg}$ vapor was dissolved into the iron even before iron melting. Under thermodynamic equilibrium condition, an oxide layer containing two components, i.e. $\mathrm{MgO} \cdot \mathrm{Al}_{2} \mathrm{O}_{3}$ phase and $\mathrm{CaO}-\mathrm{SiO}_{2}-\mathrm{MgO}-\mathrm{Al}_{2} \mathrm{O}_{3}$ phase, was generated on the surface of the iron sample. Due to the different wettability between the iron and the two phases, $\mathrm{MgO} \cdot \mathrm{Al}_{2} \mathrm{O}_{3}$ phase was repelled, while the $\mathrm{CaO}-\mathrm{SiO}_{2}-\mathrm{MgO}-\mathrm{Al}_{2} \mathrm{O}_{3}$ phase adhered to the inside area.
\end{abstract}

KEY WORDS: contact angle; wettability; liquid iron; $\mathrm{MgO}$ substrate; $\mathrm{Fe}-\mathrm{Al}$ alloy

\section{Introduction}

The choice of lining refractory material is always of great importance for the manufacturing of clean -1 -

(C) 2017. This manuscript version is made available under the Elsevier user license http://www.elsevier.com/open-access/userlicense/1.0/ 
steel. The interfacial phenomenon between the lining refractory and the liquid steel related to the erosion of the lining refractory ${ }^{[1,2]}$, the contamination of the liquid stee ${ }^{[3]}$, the removal of inclusions ${ }^{[3]}$, the nozzle clogging ${ }^{[4]}$, etc. It is of great importance to study the wettability between the liquid steel and the lining refractory to characterize the interfacial phenomenon and improve the cleanliness of steel products.

In secondary refining process, deoxidizers are added in the molten steel to lower the dissolved oxygen. Aluminum is one of the most popular deoxidizers due to its strong deoxidization ability. Recently, $\mathrm{MgO}$ containing lining refractory, such as $\mathrm{MgO}-\mathrm{C}$ brick, dolomitic brick, etc. is extensively used at steel mills. Wettability between the liquid iron and the $\mathrm{MgO}$ substrate had been widely studied in previous works ${ }^{[3,}$

${ }^{5-7]}$. Many researchers ${ }^{[8-10]}$ had studied the reaction between the Al-killed steel and the MgO-based lining refractory. However, few studies focused on the influence of $\mathrm{Al}$ in the liquid iron on the wettability between the liquid iron and $\mathrm{MgO}$.

At steelmaking temperature, the liquid steel is easy to react with refractory. The previous wetting studies mainly focused on the reaction between the liquid iron and the substrate at the interface. It was regretful that the examination of the metal drop surface was usually neglected. Shin ${ }^{[11]}$ et al. observed the climbing of the oxide layer on the surface of $\mathrm{Fe}-19 \% \mathrm{Cr}-10 \% \mathrm{Ni}$ alloys from the bottom. Nevertheless, the formation mechanism of the oxide layer was not clearly elucidated. In the current study, the wettability between $\mathrm{Fe}-\mathrm{Al}$ alloy and sintered $\mathrm{MgO}$ substrate was investigated. In particular, the formation of oxide layer on the surface of iron sample was clearly indicated based on the current experiment condition.

\section{Experimental details}

\subsection{Sample preparation}

The purity of $\mathrm{MgO}$ used for the contact angle measurement is $98.0 \%$. $\mathrm{MgO}$ powder was pressed into a thin substrate with $3 \mathrm{~mm}$ in height and $35 \mathrm{~mm}$ in diameter under a load of $200 \mathrm{MPa}$. Then the substrate was sintered at $1600{ }^{\circ} \mathrm{C}$ for 2 hours to increase its strength and hardness. Whereafter, the surface of the sintered substrate was polished by abrasive papers and a diamond paste. The surface roughness of the substrate was $0.55 \mu \mathrm{m}$, measured by a profilometer (Dektak 150). The iron was machined into a cylinder 
with $5.5 \mathrm{~mm}$ in height and $3.0 \mathrm{~mm}$ in diameter, and cleaned in ethanol using an ultrasonic cleaner. The composition of the initial iron samples are listed in Table 1. It should be noted that $\mathrm{Al}$ concentrations in the samples A and B are 18 ppm and 370 ppm respectively.

Table 1 Compositions of iron samples A and B (ppm)

\begin{tabular}{ccccccccc}
\hline Iron samples & $\mathrm{Al}$ & $\mathrm{C}$ & $\mathrm{Si}$ & $\mathrm{Mn}$ & $\mathrm{S}$ & $\mathrm{Ca}$ & $\mathrm{Mg}$ & $\mathrm{O}$ \\
\hline $\mathrm{A}$ & 18 & 5 & $<5$ & 1 & 6 & - & 4 & 70 \\
$\mathrm{~B}$ & 370 & 8 & 4 & 2.5 & 10 & 32 & 5 & 70.8 \\
\hline
\end{tabular}

\subsection{Experimental setup and procedure}

In the current study, the sessile drop method was employed to study the wettability between the liquid iron and the sintered $\mathrm{MgO}$ substrate. The contact angle measurement was conducted in a horizontal tube furnace. The experimental setup is shown in Fig. 1. Before heating, the substrate was put on an alumina plate, while the iron was placed in the center of the $\mathrm{MgO}$ substrate. The assembly was then placed in the constant temperature zone of the furnace and heated to the desired temperature at a heating rate of 5 ${ }^{\circ} \mathrm{C} / \mathrm{min}$. The alumina tube was sealed by flange plates, and the terminal was fixed with quartz glass. Argon gas mixed with 5 vol\% of $\mathrm{H}_{2}$ was introduced into the tube at a flow rate of $30 \mathrm{~L} / \mathrm{h}$. The light of a halogen lamp passed through the tube, and then the melting and wetting process were recorded by a CCD camera at a frame rate of 5 frames per minute. The movie including the image of the sample and substrate, temperature, time, etc. was recorded in a software for the measurement of contact angle.

\section{Results}

\subsection{Effect of aluminum concentration}

Fig. 2 shows the contact angles between the sintered $\mathrm{MgO}$ substrate and the liquid iron with different $\mathrm{Al}$ concentrations. The contact angle remained stable and showed the similar values during the whole heating and holding process,. It was defined that the average value of the final $60 \mathrm{~min}$ is the stable contact angle between the liquid iron and the $\mathrm{MgO}$ substrate. The measured contact angles of the iron samples A and B were $133.5^{\circ}$ and $134.6^{\circ}$, respectively.

Fig. 3 shows the morphology of the surface of iron drops after experiment. The surface of the iron $-3-$ 
with $18 \mathrm{ppm} \mathrm{Al} \mathrm{was} \mathrm{not} \mathrm{smooth,} \mathrm{which} \mathrm{might} \mathrm{be} \mathrm{caused} \mathrm{by} \mathrm{the} \mathrm{solidification} \mathrm{of} \mathrm{iron.} \mathrm{The} \mathrm{EDS} \mathrm{result}$ indicated that the composition of the surface of the iron sample with $18 \mathrm{ppm} \mathrm{Al}$ was relatively uniform Fe. However, the iron sample with $370 \mathrm{ppm} \mathrm{Al}$ was covered with an oxide layer. The morphology and composition of different areas are given in Fig. 4 and Table 2. The oxide layer mainly consisted of plenty of small $\mathrm{MgO}-\mathrm{Al}_{2} \mathrm{O}_{3}$ particles and individual iron drops. The angular shape particles should be $\mathrm{MgO} \cdot \mathrm{Al}_{2} \mathrm{O}_{3}$ spinel phase ${ }^{[12,13]}$. Fig. 5 was the elemental mapping of the iron surface. There were $\mathrm{SiO}_{2}$ and $\mathrm{CaO}$ detected in the gap of $\mathrm{MgO} \cdot \mathrm{Al}_{2} \mathrm{O}_{3}$ particles.

Table 2 Compositions of different areas analyzed using EDS (wt $\%$ )

\begin{tabular}{ccccccc}
\hline No. & $\mathrm{Fe}$ & $\mathrm{O}$ & $\mathrm{Al}$ & $\mathrm{Mg}$ & $\mathrm{Ca}$ & $\mathrm{Si}$ \\
\hline 1 & 10.4 & 56.4 & 19.9 & 9.9 & 2.4 & 1.0 \\
2 & 98.3 & 1.4 & 0 & 0.1 & 0 & 0.1 \\
3 & 1.6 & 59.7 & 23.3 & 11.7 & 2.8 & 0.9 \\
4 & 1.1 & 63.3 & 23.3 & 11.9 & 0.2 & 0.2 \\
5 & 98.9 & 0.3 & 0.3 & 0.2 & 0.2 & 0.1 \\
\hline
\end{tabular}

After the analysis of the iron surface, the substrate and the iron were cut perpendicularly from the center. The cross section of the substrate and the iron were analyzed using SEM-EDS. In Fig. 6, it should be noted that there is no reaction layer in the interface between the substrate and the iron. Several $\mathrm{CaO}-\mathrm{SiO}_{2}$ rich impurities were detected in the substrate. In Fig. 7, the oxide layer consisted of a $\mathrm{MgO} \cdot \mathrm{Al}_{2} \mathrm{O}_{3}$ outer phase and the $\mathrm{CaO}-\mathrm{SiO}_{2}-\mathrm{MgO}-\mathrm{Al}_{2} \mathrm{O}_{3}$ inner phase, agreeing with the small $\mathrm{MgO} \cdot \mathrm{Al}_{2} \mathrm{O}_{3}$ particles and the $\mathrm{SiO}_{2}$-CaO-rich gap in Fig. 5. The schematic of the distribution of the oxide layer is illustrated in Fig. 8.

\subsection{Effect of oxygen partial pressure}

It was reported that the oxidation of metal can be effectively prevented by adding $5 \mathrm{vol} \% \mathrm{H}_{2}$ in $\mathrm{Ar}$ $\operatorname{gas}^{[14,15]}$. In the current study, the volume percent of $\mathrm{H}_{2}$ in $\mathrm{Ar}$ gas was adjusted from $0 \%$ to $5 \%$ to change oxygen partial pressures. Fig. 9 shows that the oxygen partial pressure distinctly declined with the increase of $\mathrm{H}_{2}$ volume percentage. With the volume percentage of $\mathrm{H}_{2}$ exceeding $1 \%$, the oxygen partial pressure changes little. 
Fig. 10 shows the contact angle between the substrate and iron $\left(\mathrm{Al}_{\mathrm{t}}=370 \mathrm{ppm}\right)$ in different atmospheres. The contact angle slightly decreased with time. Fig. 11 shows the initial and stable contact angle in different atmospheres. When the volume percentage of $\mathrm{H}_{2}$ in the gas was higher than $1 \%$, the contact angle can hardly be changed. With $\mathrm{H}_{2}$ in the gas lower than $1 \%$, the contact angle apparently reduced with the decrease of volume percentage of $\mathrm{H}_{2}$.

Fig. 12 shows the morphology of the surface of iron samples $\left(\mathrm{Al}_{\mathrm{t}}=370 \mathrm{ppm}\right)$ after experiments. All the iron samples were covered with an oxide layer. With $\mathrm{V}\left(\mathrm{H}_{2}\right) \geqslant 1 \%$, the morphology and composition of the oxide layers were similar to that shown in Fig. 4 and Table 2. It can be seen that the iron drop was obviously oxidized in the atmosphere with $\mathrm{V}\left(\mathrm{H}_{2}\right) \leqslant 1 \%$,. The main composition of the oxide layer at the condition of $\mathrm{V}\left(\mathrm{H}_{2}\right)=0 \%$ was $\mathrm{FeO}, \mathrm{FeO}-\mathrm{Al}_{2} \mathrm{O}_{3}$, and $\mathrm{CaO}-\mathrm{SiO}_{2}$, while the oxide layer consisted of $\mathrm{FeO}$ and $\mathrm{MgO} \cdot \mathrm{Al}_{2} \mathrm{O}_{3}$ at the condition of $\mathrm{V}\left(\mathrm{H}_{2}\right)=0.6 \%$

\subsection{Effect of temperature and holding time}

In order to figure out the formation mechanism of the oxide layer on the surface of the iron $\left(\mathrm{Al}_{\mathrm{t}}=370\right.$ ppm), the holding temperature and the holding time was adjusted as listed in Table 3. In the first three experiments, the holding temperature was lower than the melting point of iron, the iron sample kept the cylinder shape after the experiment. The measured contact angles between the liquid iron drop and the substrate were generally similar in the last two experiments. The morphology of the final samples is shown in Fig. 13. When the temperature was lower than $1200{ }^{\circ} \mathrm{C}$, there are no oxides generated on the surface of the iron sample. After $30 \mathrm{~min}$ and $120 \mathrm{~min}$ holding at $1550{ }^{\circ} \mathrm{C}$, the iron samples were covered with an oxide layer with roughly the same chemistry composition. At $1525{ }^{\circ} \mathrm{C}$, a number of small individual $\mathrm{MgO} \cdot \mathrm{Al}_{2} \mathrm{O}_{3}$ particles formed on the whole surface of the solid iron sample. Fig. 14 and Fig. 15 show the elemental mapping result at the middle and the bottom of the iron surface. The $\mathrm{MgO}$ content in $\mathrm{MgO} \cdot \mathrm{Al}_{2} \mathrm{O}_{3}$ particles gradually increased with closing to the bottom of the iron sample. In the position $400 \mu \mathrm{m}$ from the bottom, the formed particles were $\mathrm{MgO}$-rich oxides.

Table 3 Experiment conditions 


\begin{tabular}{cccc}
\hline No. & Temperature $\left({ }^{\circ} \mathrm{C}\right)$ & Holding time $(\mathrm{min})$ & Atmosphere \\
\hline 1 & 25 & 0 & $\mathrm{Ar}+5 \mathrm{vol} \% \mathrm{H}_{2}$ \\
2 & 1200 & 0 & $\mathrm{Ar}+5 \mathrm{vol} \% \mathrm{H}_{2}$ \\
3 & 1525 & 0 & $\mathrm{Ar}+5 \mathrm{vol} \% \mathrm{H}_{2}$ \\
4 & 1550 & 30 & $\mathrm{Ar}+5 \mathrm{vol} \% \mathrm{H}_{2}$ \\
5 & 1550 & 120 & $\mathrm{Ar}+5 \mathrm{vol} \% \mathrm{H}_{2}$ \\
\hline
\end{tabular}

\section{Discussion}

\subsection{Formation of the $\mathrm{MgO} \cdot \mathrm{Al}_{2} \mathrm{O}_{3}$ particles}

Due to the high concentration of $\mathrm{Al}$ in the $\mathrm{Fe}-\mathrm{Al}$ alloy, it was expected that the dissolved $\mathrm{Al}$ might react with $\mathrm{MgO}^{[16,17]}$ as Eq.(1). However, there was no reaction layer detected in the interface between the substrate and the iron drop in Fig. 6, indicating that the formation of the oxide layer on the surface of iron was not dominated by reaction 1 . Besides, the formation of $\mathrm{MgO} \cdot \mathrm{Al}_{2} \mathrm{O}_{3}$ particles on the surface of the cylinder iron sample at $1525{ }^{\circ} \mathrm{C}$ could hardly be explained by reaction 1 .

$$
2[\mathrm{Al}]+4 \mathrm{MgO}=\mathrm{MgO} \cdot \mathrm{Al}_{2} \mathrm{O}_{3}+3[\mathrm{Mg}]
$$

Due to the reducing atmosphere, the $\mathrm{MgO}$ substrate might be reduced to $\mathrm{Mg}$ vapor as reactions in Eqs. (2) and (3). According to the measured oxygen partial pressure, the equilibrium partial pressure of $\mathrm{Mg}$ vapor in the gas can be calculated by Eqs. (2) and (3), as expressed in Fig. 16. The partial pressure of Mg vapor distinctly dropped to a low level with the decrease of temperature, indicating that reaction 2 can hardly occur at the low temperature. At the temperature higher than $1500{ }^{\circ} \mathrm{C}$, the equilibrium partial pressure of $\mathrm{Mg}$ vapor goes up, especially under the condition that Ar gas with higher than 1 vol\% $\mathrm{H}_{2}$. The Mg vapor may dissolve into the alloy even before the melting of alloy. The initial Mg concentration in the alloy was $5 \mathrm{ppm}$. The formation of inclusions on the surface of the iron with the $\mathrm{Mg}$ concentration from $5 \mathrm{ppm}$ to $40 \mathrm{ppm}$ was predicted using FactSage 7.0. With the Mg concentration lowering than 15 ppm, the formed solid oxides are mainly $\mathrm{CaO}-\mathrm{Al}_{2} \mathrm{O}_{3}$ and $\mathrm{MgO} \cdot \mathrm{Al}_{2} \mathrm{O}_{3}$. With the $\mathrm{Mg}$ concentration reaching $20 \mathrm{ppm}$, the oxides transformed to $\mathrm{MgO} \cdot \mathrm{Al}_{2} \mathrm{O}_{3}$, as shown in Fig. 17, in consistent with the observed results. At $1525^{\circ} \mathrm{C}$, the $\mathrm{Mg}$ vapor leads to the formation of the individual $\mathrm{MgO} \cdot \mathrm{Al}_{2} \mathrm{O}_{3}$ particles on the surface of the unmelted solid iron as reaction $4^{[16]}$. Moreover, the detected $\mathrm{CaO}-\mathrm{SiO}_{2}-\mathrm{MgO}-\mathrm{Al}_{2} \mathrm{O}_{3}$ 
phase agrees with the calculated slag phase and $\mathrm{SiO}_{2}$, which might be from the impurities in the substrate. In Fig. 15, the formation of $\mathrm{MgO}$ particles formed at the bottom of the iron sample may be caused by the stronger dissolution of $\mathrm{Mg}$ in the iron, which is in line with the predicted phases in the Fe-Al alloy containing 40 ppm Mg in Fig. 18.

$$
\begin{aligned}
& \mathrm{MgO}(\mathrm{s})+\mathrm{H}_{2}(\mathrm{~g})=\mathrm{Mg}(\mathrm{g})+\mathrm{H}_{2} \mathrm{O}(\mathrm{g}), \quad \Delta \mathrm{G}^{\theta}=479600-147.32 \mathrm{~T} \\
& 2 \mathrm{H}_{2}(\mathrm{~g})+\mathrm{O}_{2}(\mathrm{~g})=2 \mathrm{H}_{2} \mathrm{O}(\mathrm{g}), \quad \Delta \mathrm{G}^{\theta}=-493070+109.88 \mathrm{~T} \\
& {[\mathrm{Mg}]+[\mathrm{Al}]+[\mathrm{O}]=\mathrm{MgO} \cdot \mathrm{Al}_{2} \mathrm{O}_{3}, \quad \Delta \mathrm{G}^{\theta}=977914-129 \mathrm{~T}}
\end{aligned}
$$

\subsection{Separation of two oxide phases}

In Fig. 8, there were two oxide phases, the outer phase was mainly $\mathrm{MgO} \cdot \mathrm{Al}_{2} \mathrm{O}_{3}$ particles, the inner phase was liquid $\mathrm{CaO}-\mathrm{SiO}_{2}-\mathrm{MgO}-\mathrm{Al}_{2} \mathrm{O}_{3}$ slag. The contact angle between the $\mathrm{MgO} \cdot \mathrm{Al}_{2} \mathrm{O}_{3}$ and the pure iron was usually larger than $90^{\circ}\left(\theta_{1}>90^{\circ}\right)^{[7,18,19]}$, while the contact angle between the liquid oxide phase and the pure iron was usually smaller than $90^{\circ}\left(\theta_{2}<90^{\circ}\right)^{[3]}$.

In Fig. 19, it is assumed that there is a rigid flat substrate made of $\mathrm{MgO} \cdot \mathrm{Al}_{2} \mathrm{O}_{3}$ and $\mathrm{CaO}-\mathrm{SiO}_{2}-\mathrm{MgO}-\mathrm{Al}_{2} \mathrm{O}_{3}$, respectively. The liquid iron drop forms in the center of the substrate contacting the two oxide phases. The initial contact angles at both left and right sides were assumed to be the same. Obviously, the initial state is not in equilibrium. It is defined that the force direction is positive when pointing to the right. The residual force acts on left side and right side can be calculated by Eqs. (5) and (6). Under the current assumptions, the left stable contact angle is $\theta_{1}$, while the right stable contact angle,

$\theta_{2}$, might be a little different from its true contact angle, $\theta_{2}{ }^{[3]}$. However, $\theta_{2}{ }^{\prime}$ should be still smaller than $90^{\circ}$.

$$
\begin{aligned}
& F_{1}=\gamma_{l} \cos \theta+\gamma_{s 1-l}-\gamma_{s 1} \\
& F_{2}=\gamma_{s 2}-\gamma_{l} \cos \theta-\gamma_{s 2-l}
\end{aligned}
$$

In the case that the liquid drop and the left substrate is in equilibrium, i.e. $\theta=\theta_{1}>90^{\circ}$, it can be inferred $\mathrm{F}_{1}=0$. Meanwhile, $\theta>90^{\circ}>\theta_{2}^{\prime}$, then $\mathrm{F}_{2}>0$. Consequently, the right side of the iron drop moves in the right 
direction, leading to the decrease of left contact angle, and then $F_{1}>0$. As a result, the left side of the iron drop also moves in the right direction. In conclusion, the iron drop prefers to wet the $\mathrm{CaO}-\mathrm{SiO}_{2}-\mathrm{MgO}-\mathrm{Al}_{2} \mathrm{O}_{3}$ phase and repel the $\mathrm{MgO} \cdot \mathrm{Al}_{2} \mathrm{O}_{3}$ phase. In the case that the liquid drop and the right substrate is in equilibrium, i.e. $\theta=\theta_{2}{ }^{\prime}<90^{\circ}$, the iron drop also moves in the right direction. Therefore, the formed $\mathrm{MgO} \cdot \mathrm{Al}_{2} \mathrm{O}_{3}$ phase and $\mathrm{CaO}-\mathrm{SiO}_{2}-\mathrm{MgO}-\mathrm{Al}_{2} \mathrm{O}_{3}$ phase on the surface of the iron drop shown in Fig. 8 shows the stable two phases distribution.

\section{Conclusion}

(1) The measured contact angles between the sintered $\mathrm{MgO}$ substrate and the liquid iron were approximately $134^{\circ}$, hardly influenced by $\mathrm{Al}$ concentrations of $18 \mathrm{ppm}$ and $370 \mathrm{ppm}$ in the liquid iron.

(2) The $\mathrm{MgO}$ substrate was reduced by $\mathrm{H}_{2}$ at the high temperature, leading to the formation of $\mathrm{Mg}$ vapor even before the melting of the iron. The Mg vapor dissolved into the iron with $370 \mathrm{ppm} \mathrm{Al}$, resulting in the formation of an oxide layer on the surface of the iron sample. The oxide layer containing two components, i.e. $\mathrm{MgO} \cdot \mathrm{Al}_{2} \mathrm{O}_{3}$ phase and $\mathrm{CaO}-\mathrm{SiO}_{2}-\mathrm{MgO}-\mathrm{Al}_{2} \mathrm{O}_{3}$ phase. Due to the different wettability between the iron and the two phases, $\mathrm{MgO} \cdot \mathrm{Al}_{2} \mathrm{O}_{3}$ phase was repelled, while the $\mathrm{CaO}-\mathrm{SiO}_{2}-\mathrm{MgO}-\mathrm{Al}_{2} \mathrm{O}_{3}$ phase adhered to the inside area.

(3) With $\mathrm{V}\left(\mathrm{H}_{2}\right) \geq 1 \%$, the contact angle changed little due to the similar oxygen partial pressure. There was an oxide layer formed on the iron drop without the oxidation of iron drop. With $\mathrm{V}\left(\mathrm{H}_{2}\right) \leq 1 \%$, the contact angle reduced with the decrease of the volume percent of $\mathrm{H}_{2}$. The iron sample was obviously oxidized and FeO-rich oxides may form on the surface of the iron drop.

\section{Acknowledgements}

The authors are grateful for support from the National Science Foundation China (Grant No. 51274034, No. 51334002, No. 51604023, No. 51504020, and No. 51404019), Beijing Key Laboratory of Green Recycling and Extraction of Metals (GREM), the Laboratory of Green Process Metallurgy and Modeling 
$\left(\mathrm{GPM}^{2}\right)$ and the High Quality steel Consortium (HQSC) at the School of Metallurgical and Ecological Engineering at University of Science and Technology Beijing (USTB), China.

\section{References}

[1] Z. Yuan, Y. Wu, H. Zhao, et al. Wettability between molten slag and MgO-C refractories for the slag splashing process[J]. ISIJ International, 2013, 53(4): 598-602.

[2] S. H. Heo, K. Lee, Y. Chung. Reactive wetting phenomena of MgO-C refractories in contact with $\mathrm{CaO}-\mathrm{SiO}_{2} \operatorname{slag}[\mathrm{J}]$. Transactions of Nonferrous Metals Society of China, 2012, 22(S3): 870-875.

[3] A. W. Cramb, I. Jimbo. Interfacial considerations in continuous casting[J]. Iron \& Steelmaker, 1989, 16(6): 43-55.

[4] C. Bernhard, G. Xia, A. Karasangabo, et al. Investigating the influence of Ti and P on the clogging of ULC steels in the continuous casting process[J]. World Iron \& Steel, 2012, (5): 19-28.

[5] C. Xuan, H. Shibata, S. Sukenaga, et al. Wettability of $\mathrm{Al}_{2} \mathrm{O}_{3}, \mathrm{MgO}$ and $\mathrm{Ti}_{2} \mathrm{O}_{3}$ by liquid iron and steel[J]. ISIJ International, 2015, 55(9): 1882-1890.

[6] K. Ogino, A. Adachi, K. Nogi. The wettability of solid oxides by liquid iron[J]. Tetsu-to-Hagane, 1973, 59(9): 1237-1244.

[7] H. Shibata, Y. Watanabe, K. Nakajima, et al. Degree of undercooling and contact angle of pure iron at $1933 \mathrm{~K}$ on single-crystal $\mathrm{Al}_{2} \mathrm{O}_{3}, \mathrm{MgO}$, and $\mathrm{MgAl}_{2} \mathrm{O}_{4}$ under argon atmosphere with controlled oxygen partial pressure[J]. ISIJ International, 2009, 49(7): 985-991.

[8] W. Yang, L. Zhang, H. Duan, et al. Formation of non-metallic inclusions in the molten steel in MgO crucibles[C]. EPD Congress 2014 Proceddings, TMS 2014 Annual Meeting \& Exhibition. San Diego, 
CA, USA, Febraury 16-20, 2014: TMS, 2014: 269-276.

[9] V. Brabie. A study on the mechanism of reaction between refractory materials and aluminium deoxidised molten steel[J]. Steel research, 1997, 68(2): 54-60.

[10] J. Lehmann, M. Boher, M. Kaerle. An experimental study of the interactions between liquid steel and a MgO-based tundish refractory[J]. CIM bulletin, 1997, 90(1013): 69-74.

[11] M. Shin, J. Lee, P. Joo-Hyun. Wetting Characteristics of Liquid Fe-19\%Cr-10\%Ni Alloys on Dense Alumina Substrates[J]. ISIJ International, 2008, 48(12): 1665-1669.

[12] S. Yang, Q. Wang, L. Zhang, et al. Formation and modification of $\mathrm{MgO} \cdot \mathrm{Al}_{2} \mathrm{O}_{3}$-based inclusions in alloy steels[J]. Metallurgical and Materials Transactions B, 2012, 43(4): 731-750.

[13] J. H. Park, H. Todoroki. Control of $\mathrm{MgO} \cdot \mathrm{Al}_{2} \mathrm{O}_{3}$ spinel inclusions in stainless steels[J]. ISIJ international, 2010, 50(10): 1333-1346.

[14] S. Ueda, A. W. Cramb, H. Shi, et al. The contact angle between liquid iron and a single crystal, alumina substrate at $1873 \mathrm{~K}$ : Effects of oxygen and droplet size[J]. Metallurgical \& Materials Transactions B, 2003, 34(5): 503-508.

[15] G. Parry, O. Ostrovski. Wetting of solid iron, nickel and platinum by liquid $\mathrm{MnO}^{-\mathrm{SiO}_{2}}$ and $\mathrm{CaO}-\mathrm{Al}_{2} \mathrm{O}_{3}-\mathrm{SiO}_{2}[\mathrm{~J}]$. ISIJ International, 2009, 49(6): 788-795.

[16] L. Zhang, Y. Ren, H. Duan, et al. Stability diagram of Mg-Al-O system inclusions in molten steel[J]. Metallurgical \& Materials Transactions B, 2015, 46(4): 1809-1825.

[17] S. Won-Gap, W. H. Han, K. Jeong-Sik, et al. Deoxidation equilibria among $\mathrm{Mg}, \mathrm{Al}$ and $\mathrm{O}$ in liquid iron in the presence of $\mathrm{MgO} \cdot \mathrm{Al}_{2} \mathrm{O}_{3}$ spinel[J]. ISIJ International, 2003, 43(2): 201-208.

[18] N. Shinozaki, N. Echida, K. Mukai, et al. Wettability of $\mathrm{Al}_{2} \mathrm{O}_{3}-\mathrm{MgO}, \mathrm{ZrO}_{2}-\mathrm{CaO}, \mathrm{Al}_{2} \mathrm{O}_{3}-\mathrm{CaO}$ -10 - 
substrates with molten iron[J]. Tetsu-to-Hagane, 1994, 80(10): 748-753.

[19] N. Fukami, R. Wakamatsu, N. Shinozaki, et al. Wettability between porous $\mathrm{MgAl}_{2} \mathrm{O}_{4}$ substrates and molten iron[J]. Journal of the Japan Institute of Metals, 2009, 50(11): 2552-2556. 


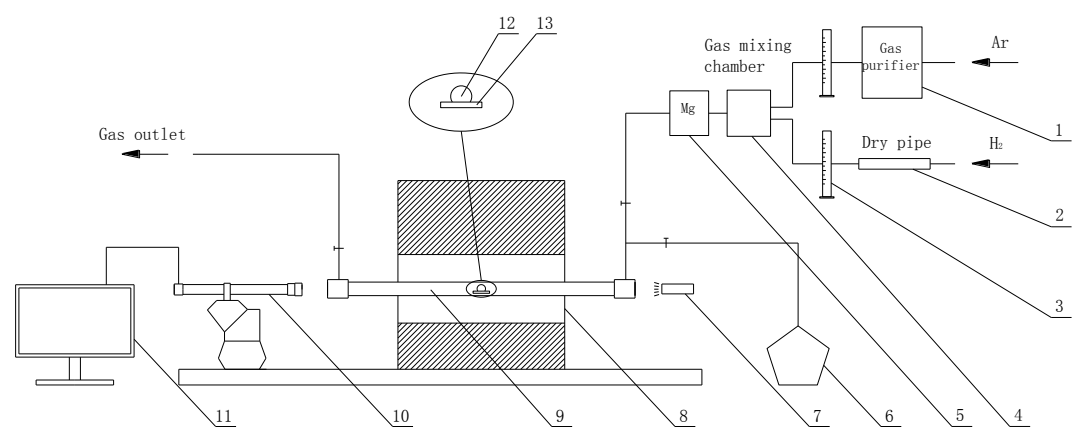

1- argon purification device; 2-dry pipe; 3- gas flowmeter; 4-Gas mixing chamber; 5-Mg furnace; 6-vacuum pump;

7-halogen light; 8-resistance furnace; 9-alumina tube; 10-CCD camera; 11-computer; 12-metal sample; 13-substrate

Fig. 1 Schematic of the experiment setup

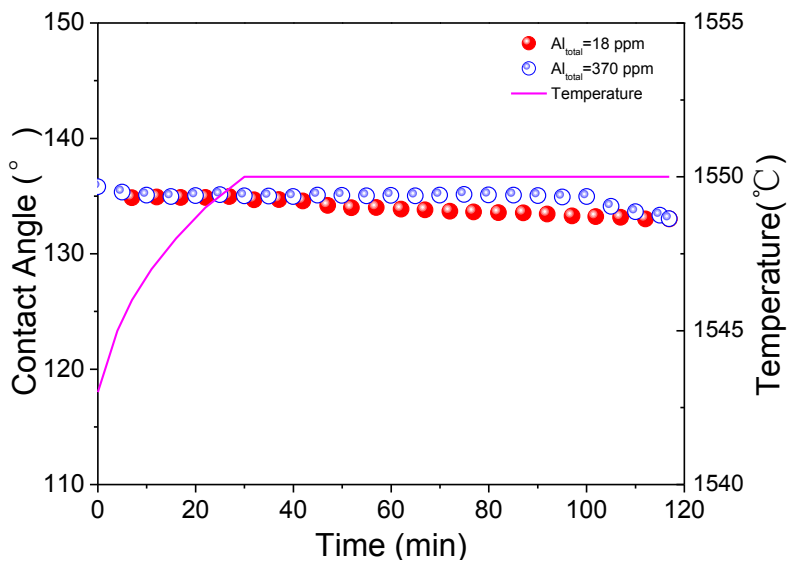

Fig. 2 Contact angles between sintered $\mathrm{MgO}$ substrates and $\mathrm{Fe}-\mathrm{Al}$ alloys

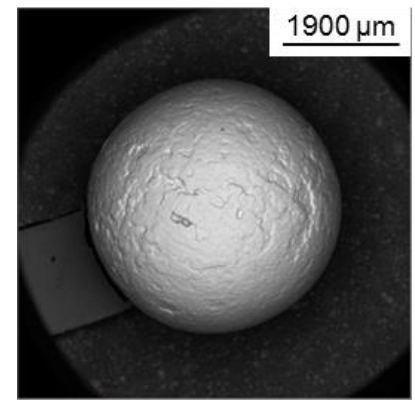

(a) $\mathrm{Al}_{\mathrm{t}}=18 \mathrm{ppm}$

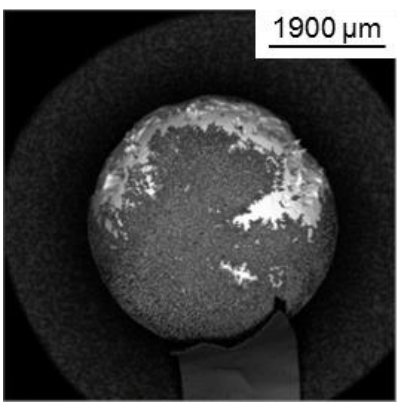

(b) $\mathrm{Al}_{\mathrm{t}}=370 \mathrm{ppm}$

Fig. 3 Surface morphology of the iron after experiment 


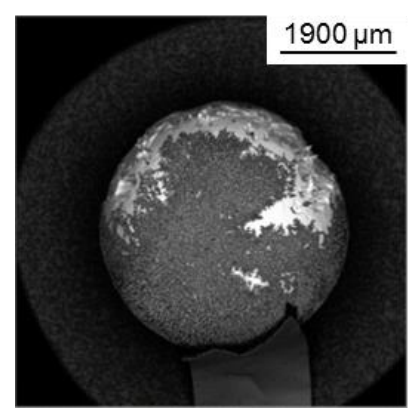

(a) $25 x$

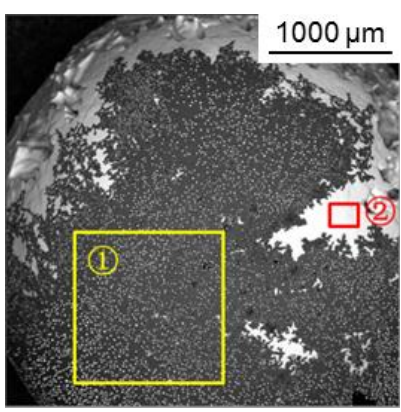

(b) $500 x$

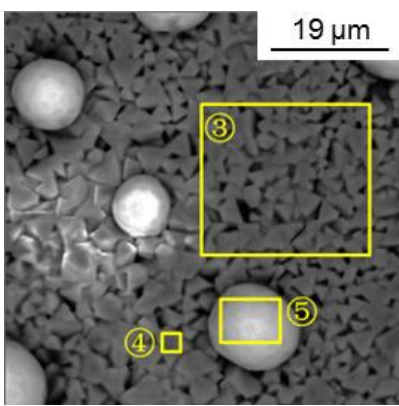

(c) $2500 x$

Fig. 4 SEM image of the iron surface $\left(\mathrm{Al}_{\mathrm{t}}=370 \mathrm{ppm}\right)$
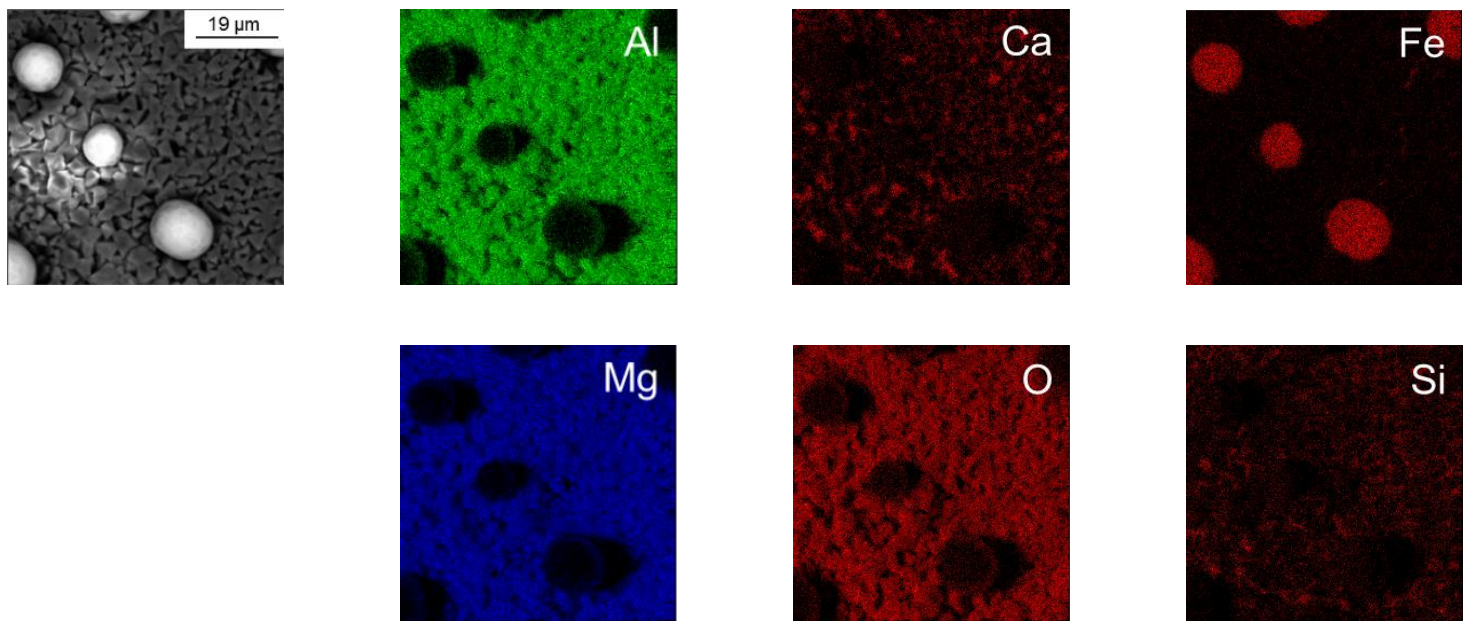

Fig. 5 Mapping of the iron surface $\left(\mathrm{Al}_{\mathrm{t}}=370 \mathrm{ppm}\right)$
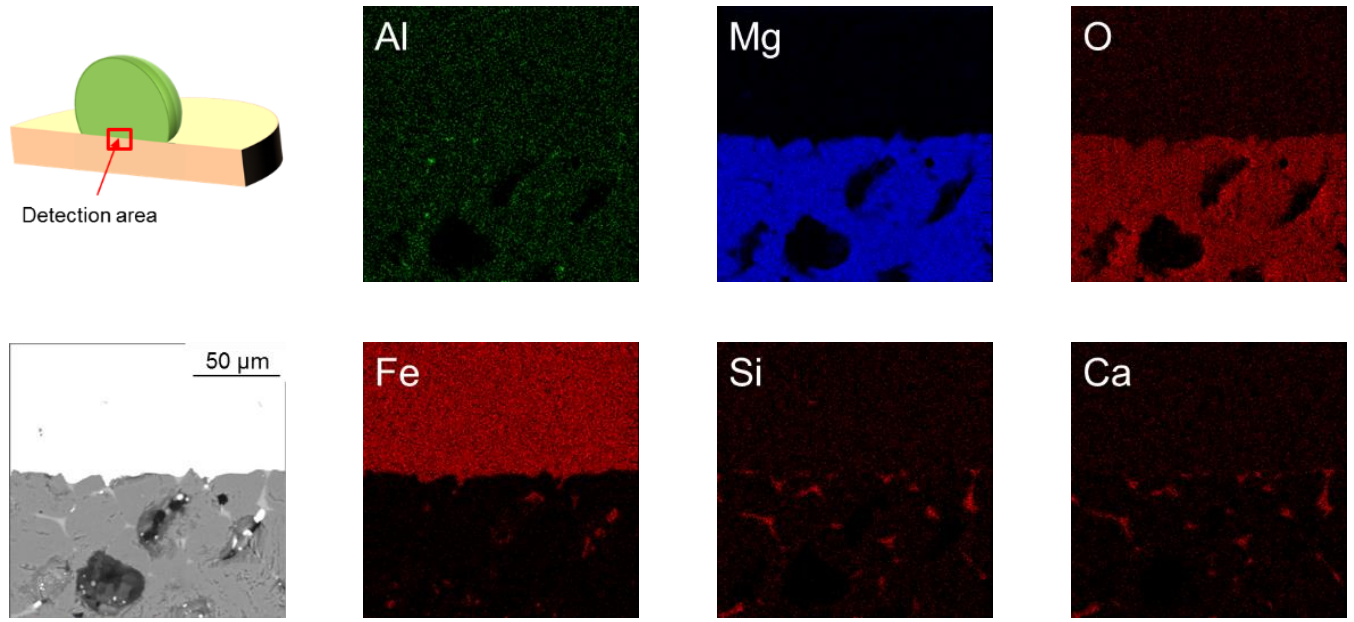

Fig. 6 Mapping of the interface between substrate and iron $\left(\mathrm{Al}_{\mathrm{t}}=370 \mathrm{ppm}\right)$ 

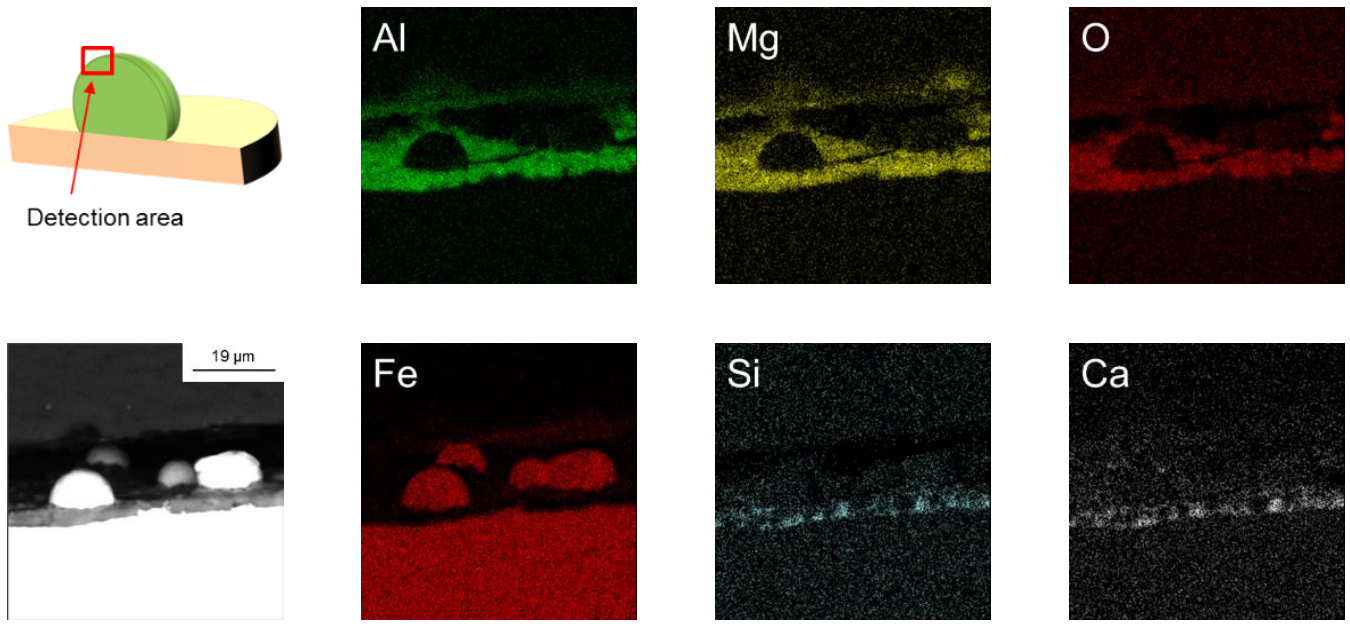

Fig. 7 Mapping of the surface of the iron $\left(\mathrm{Al}_{\mathrm{t}}=370 \mathrm{ppm}\right)$

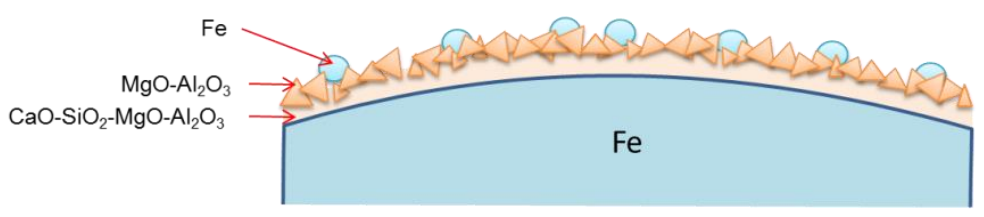

Fig. 8 Schematic of the surface of the iron $\left(\mathrm{Al}_{\mathrm{t}}=370 \mathrm{ppm}\right)$

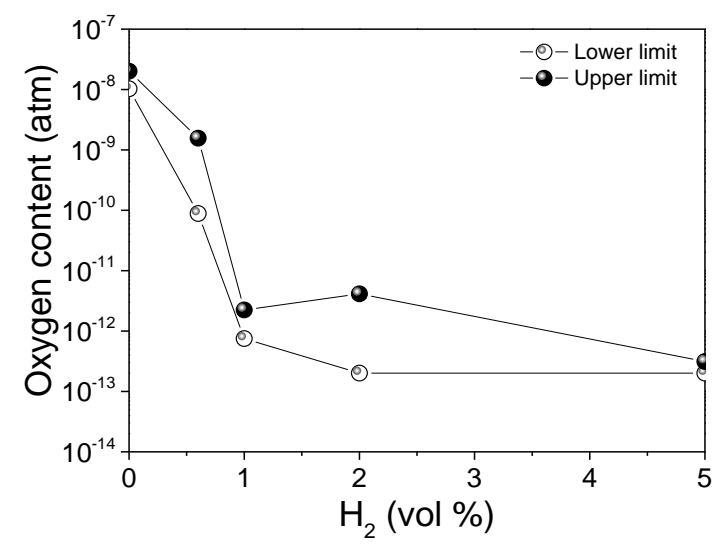

Fig. 9 Oxygen partial pressure in the gas 


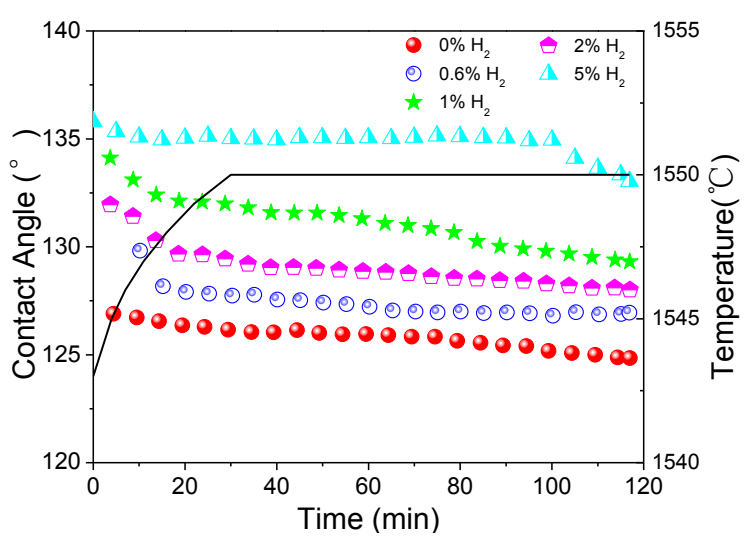

Fig. 10 Contact angle in Ar gas with different volume percent of $\mathrm{H}_{2}$

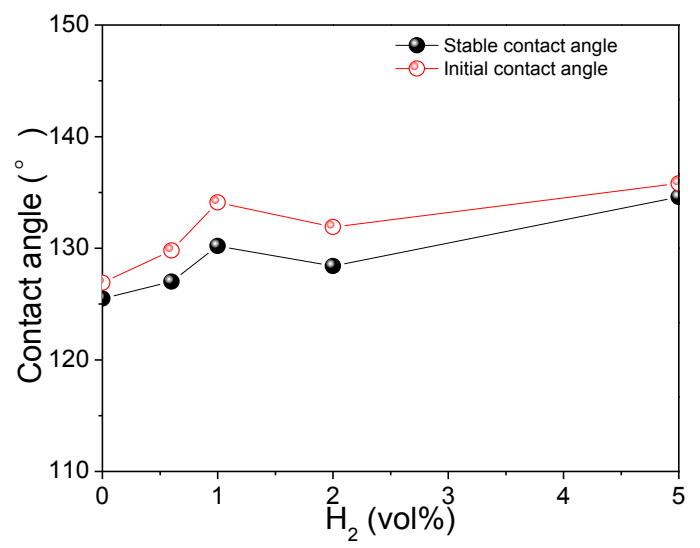

Fig. 11 The stable contact angle in Ar gas with different volume percentage of $\mathrm{H}_{2}$

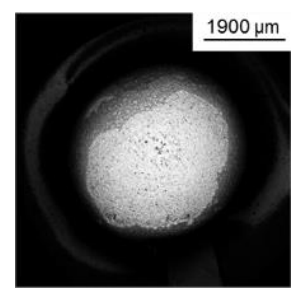

(a) $0 \% \mathrm{H}_{2}$

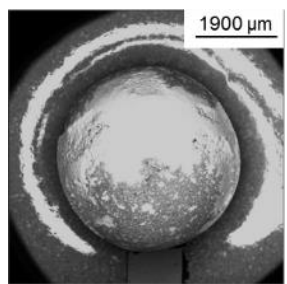

(b) $0.6 \% \mathrm{H}_{2}$

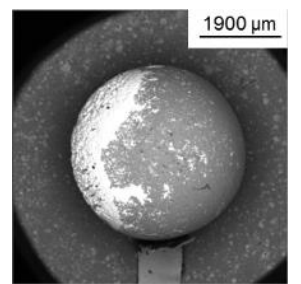

(c) $1 \% \mathrm{H}_{2}$

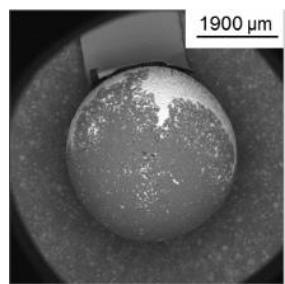

(d) $2 \% \mathrm{H}_{2}$

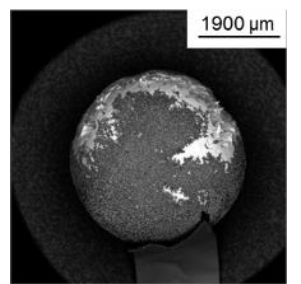

(e) $5 \% \mathrm{H}_{2}$

Fig. 12 Surface morphology of the iron after experiment in different conditions
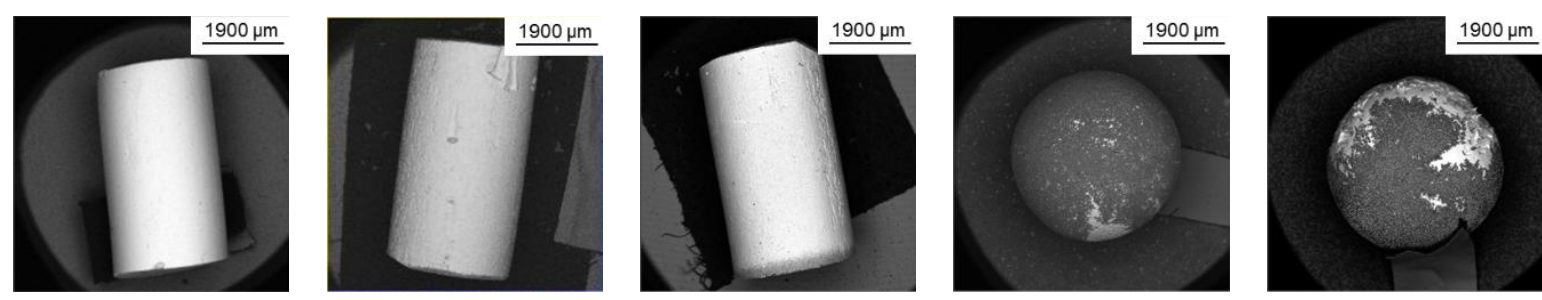


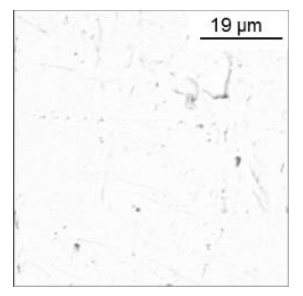

(a) $25{ }^{\circ} \mathrm{C}$,

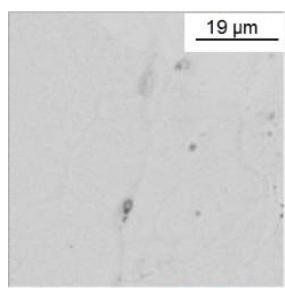

(b) $1200{ }^{\circ} \mathrm{C}$,

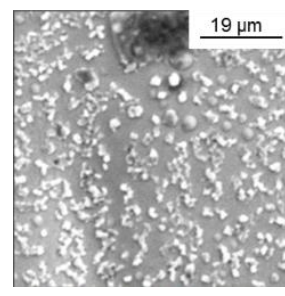

(c) $1525^{\circ} \mathrm{C}$,

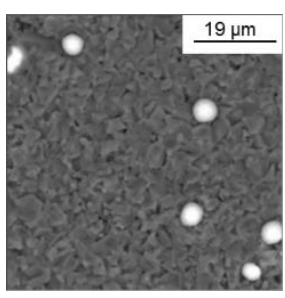

(d) $1550{ }^{\circ} \mathrm{C}$,

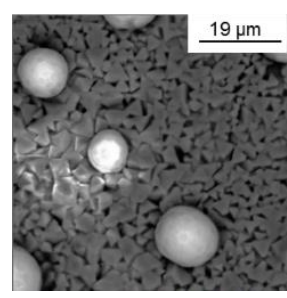

(e) $1550{ }^{\circ} \mathrm{C}$,

$0 \min$

$0 \min$

$0 \min$

$30 \min$

$120 \min$

Fig. 13 Surface morphology of the iron after experiment in different conditions
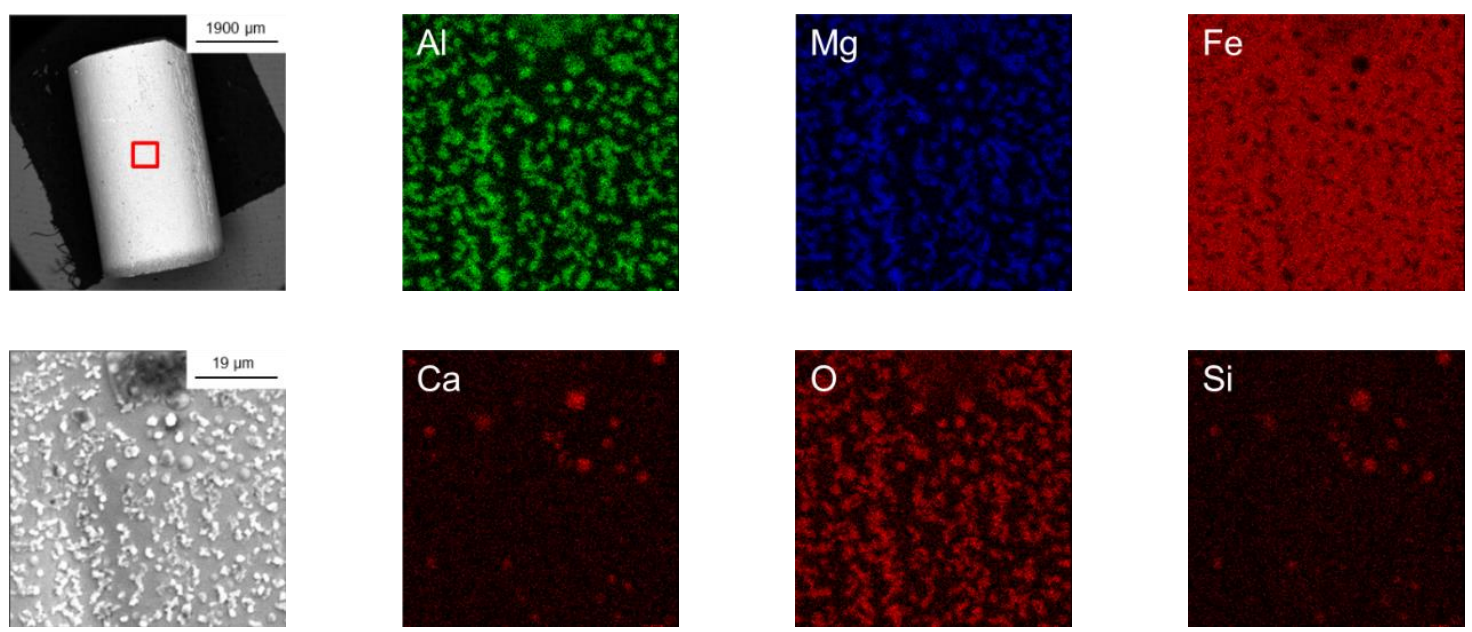

Fig. 14 Mapping of the iron surface in the middle $\left(1525^{\circ} \mathrm{C}, 0 \mathrm{~min}\right)$
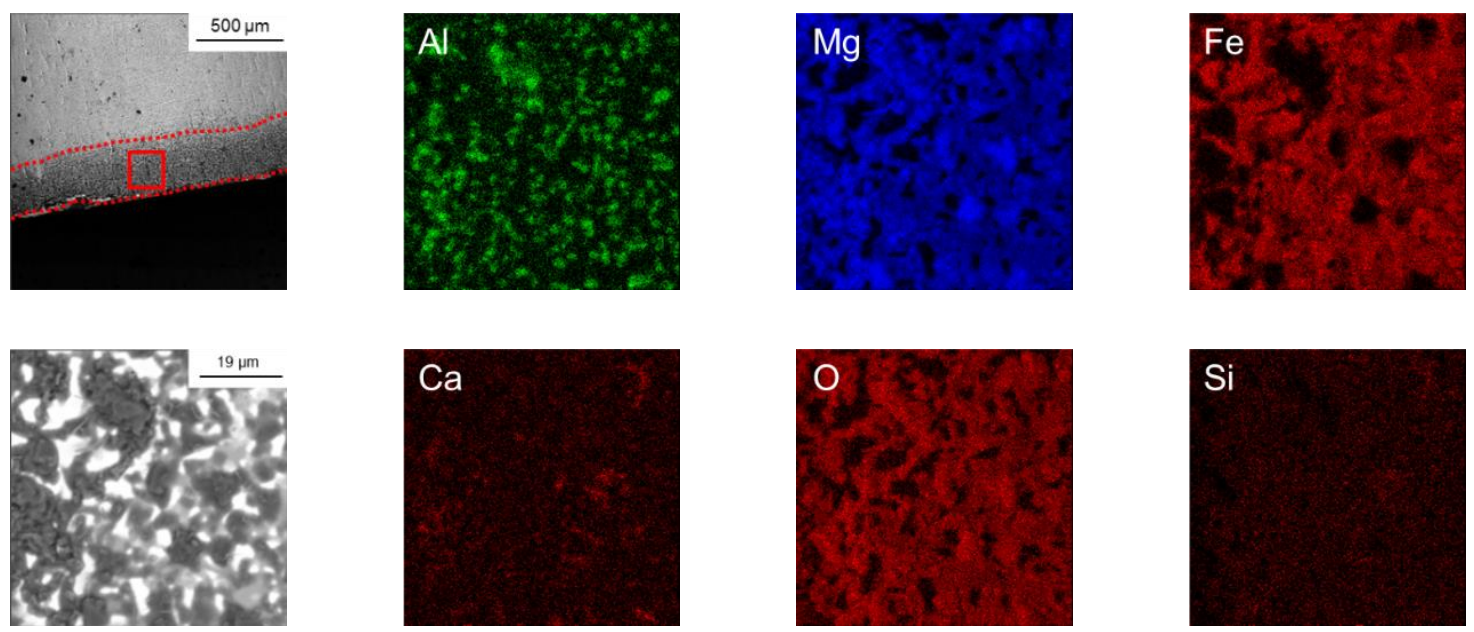

Fig. 15 Mapping of the iron surface at the bottom $\left(1525^{\circ} \mathrm{C}, 0 \mathrm{~min}\right)$ 


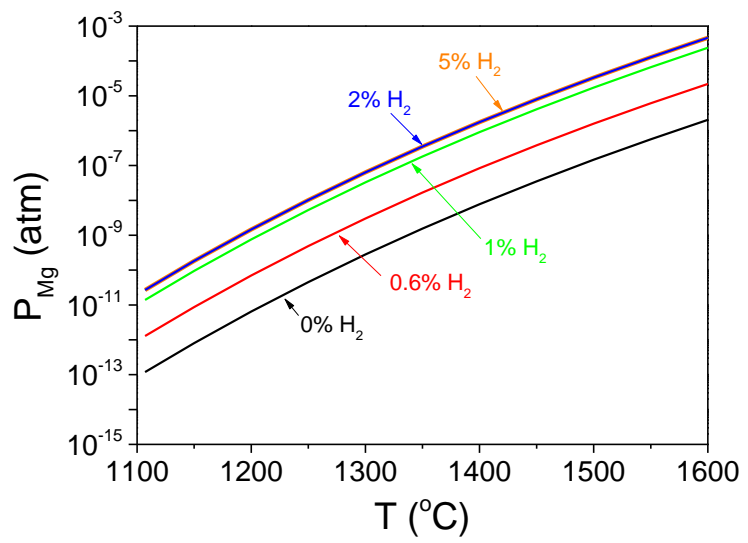

Fig. 16 Equilibrium partial pressure of $\mathrm{Mg}$ vapor

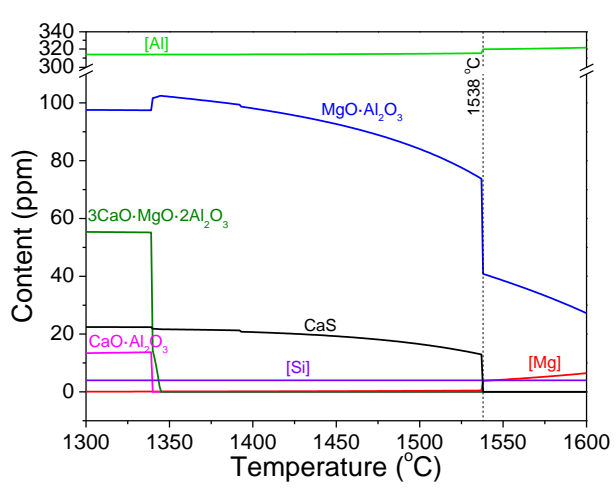

(a) Main composition in iron

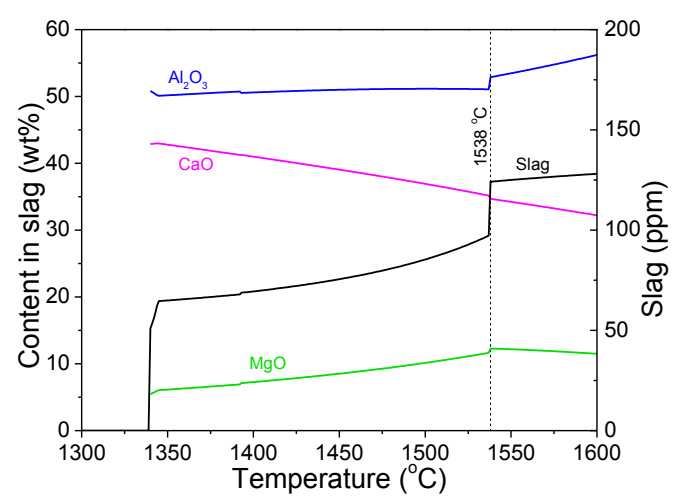

(b) Main composition in slag

Fig. 17 Thermodynamic equilibrium phases at different temperatures (20 ppm $\mathrm{Mg}$ )

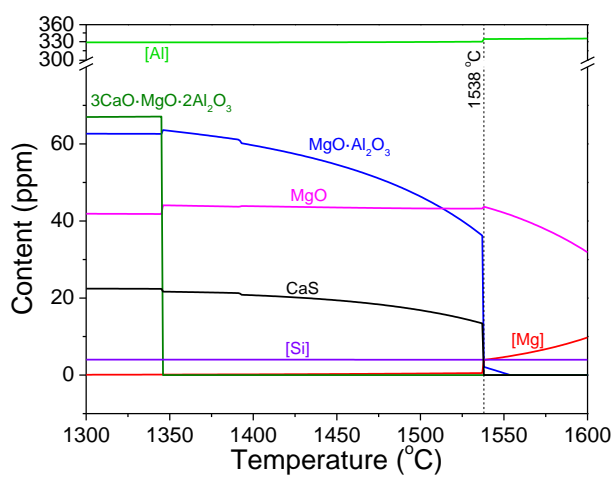

(a) Main composition in iron

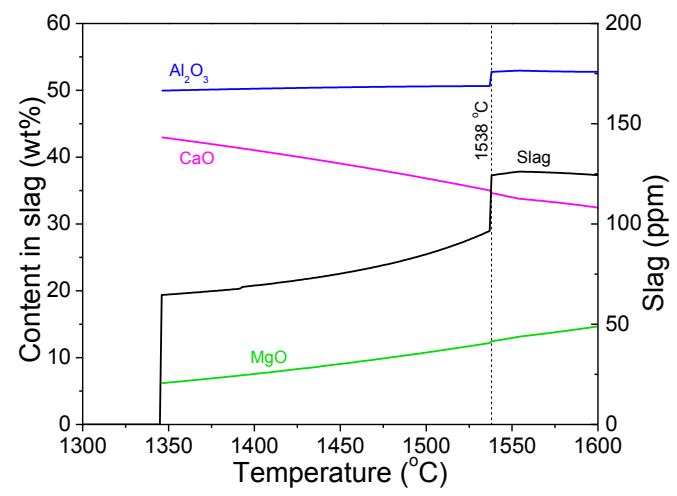

(b) Main composition in slag

Fig. 18 Thermodynamic equilibrium phases at different temperatures (40 ppm Mg) 


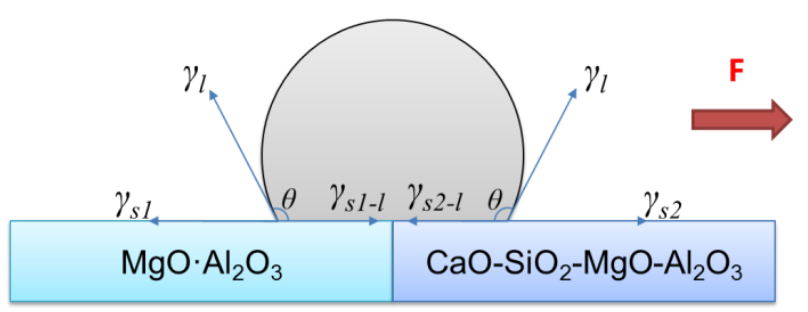

Fig. 19 Schematic of the iron drop lies on the substrate 